\title{
Educator Competences in Sustainability Education: A Systematic Review of Frameworks
}

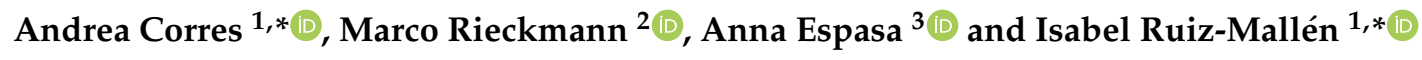 \\ 1 Internet Interdisciplinary Institute (IN3), Universitat Oberta de Catalunya, Av. Carl Friedrich Gauss, \\ 5, 08860 Castelldefels, Barcelona, Spain \\ 2 Department of Education, Faculty of Education and Social Sciences, University of Vechta, Driverstraße 22, \\ 49377 Vechta, Germany; marco.rieckmann@uni-vechta.de \\ 3 Faculty of Psychology and Education, Universitat Oberta de Catalunya, Rambla del Poblenou, \\ 156, 08018 Barcelona, Spain; aespasa@uoc.edu \\ * Correspondence: acorres@uoc.edu (A.C.); iruiz_mallen@uoc.edu (I.R.-M.)
}

Received: 30 October 2020; Accepted: 21 November 2020; Published: 25 November 2020

check for updates

\begin{abstract}
The design and use of competence frameworks and models for educators in Sustainability 3iEducation is a growing field of study that seeks to guide their professional development while identifying, examining, and assessing the competences they need. In this article we conduct a systematic review of the frameworks and models of sustainability competences addressed to teachers and other educators to shed light on (a) the backgrounds of the analyzed frameworks, (b) the conceptual and pedagogical approaches towards sustainability and competences behind them, (c) the different types of educators' competences included and particularly those addressed to promote transformational perspectives, and (d) the pedagogical strategies applied to develop them. We analyzed 14 papers out of an initial sample of 437. Findings show that all are developed in Europe. Most of them rely on the United Nations Economic Commission for Europe (UNECE) framework and its guiding approach of Education for Sustainable Development. A few others critically approach sustainability and recognize its contradictions even though they subscribe within this broad sustainability approach. The most common competences are Critical Thinking, Participation in Community, and Connections, which have been identified as those that educators need to face current sustainability challenges from a critical and transformative perspective. However, other competences significantly associated with transformational education such as Emotions Management, Futures and Achieving Transformation are less addressed and receive less attention in terms of the pedagogical strategies needed to promote them. We discuss how the different ways of understanding and operationalizing sustainability and competences behind these frameworks can shape educators' transformational capacities in Sustainability Education. Further research should address the identified challenges and provide educators with practical and suitable tools for transformative education.
\end{abstract}

Keywords: competencies; education for sustainable development; environmental education; teachers; transformation

\section{Introduction}

In the face of current socio-environmental challenges, being an educator is a complicated task. It entails the mastery of diverse competences that include a variety of skills and types of professional knowledge but also being critically aware of the factors causing unsustainable lifestyles and social and environmental injustice inside and outside school [1]. International education institutions argue that educators' role should be far from promoting unreflective conformity about these concerning issues among students. Instead, educators should develop students' critical thinking and independent 
judgment [2]. Following this view, contemporary education has been trying to make the transition from the traditional understanding that learning is about acquiring specific knowledge as a result of a process of transmitting-receiving information. In recent years, constructivist and sociocultural approaches have gained ground. These approaches state that learning is a process of construction of meaning through the acquisition of competences, in which the social and dialogic aspects are essential [3].

In this line, it has been argued that competence-based education and associated transformational education perspectives have the potential to promote students' dialogue and openness toward others. These perspectives can generate deep learning processes based on discussion and reflection to educating them to be autonomous, critical and active citizens, able to deal with social-ecological challenges [4]. However, on occasions, competence-based approaches pretend to be established as technique prescriptions without conceptual reflection and theoretical frameworks around how learning is conceived, tending to bare in a pragmatic and reductionist vision. Such vision can limit competences design and evaluation to the domain of "knowing how to do", which is punctual and procedural, out of context, as a way to define and register discrete and fragmented behavioral tasks [5]. By contrast, it is argued that the very core of the competence-based approaches should be: "self-regulated action, involving know, know to do and be, with social relevance, building situations of constructive, complex and collaborative learning towards real problem solution" [5] (p. 52). Thus, competences can be understood as "individual dispositions to self-organization which include cognitive, affective, volitional (with deliberate intention) and motivational elements; they are an interplay of knowledge, capacities and skills, motives and affective dispositions." [6] (p. 129).

Additionally, for decades, one of the clearest goals of education has been in line with ensuring growth, growth that has been linked to well-being for all [2]. However when patters of production of these attempts to grow are unsustainable and inequitable, like the ones causing the current environmental crisis and climate emergency, contradictions emerge in the core of education, and consequently, also within Sustainability Education. Referred to also as Education for Sustainability (EfS), Education for Sustainable Development (ESD) and, earlier, Environmental Education (EE), Sustainability Education aims to help learners develop the necessary knowledge, skills, values, capabilities and overall competences to respond to the complex socio-ecological issues of the 21st century [7]. Nevertheless, there has been considerable debate around the conceptualizations behind these different terminologies. For instance, some scholars have argued that EE and ESD emerged from diverse streams of thought and practice, holding ideological and ethical roots that are related to different focuses of attention and representations of environmental and development issues [8,9]. Under this view, the hegemonic concept of ESD conceives that development and growth are possible in terms of sustainability whereas more transformative EE and ESD approaches ask for an economic system acknowledging the bio-physic limits of the planet [8]. In this same line, it has been specifically pointed out that:

“(... Ameliorating issues of sustainability involves addressing ethical questions, for instance, regarding the injustice in sharing the use of the world's resources $(. .$.$) looking at issues of$ development, justice peace and conflict, human rights and dignity, and intrinsic value of other special, and indeed, whole ecosystems." [9] (p. 223)

More recent post-sustainability debates have launched the idea that any form of Sustainability Education is an opportunity for enhancing ethical reflection on growth, development and other socio-economic, political, cultural, and ecological issues shaping sustainability. For instance, it has been argued that " $(. .$.$) Sustainability Education does not signify an a priori image of sustainability$ nor defines what the education pathway towards achieving sustainability should be. Instead, it opens up possibilities for critical discussions on sustainability and suggests a process that is always in-becoming" [10] (p. 96). Consequently, regardless of the use of ESD or EE in the literature, it takes relevance to look at how any form of Sustainability Education aims to embrace critical approaches towards sustainability itself. Furthermore, it is interesting to explore to which extent they provoke transformative changes towards the current unsustainable reality through developing emancipatory 
qualities among educators, and finally among students. In other words: “ $(\ldots)$ what will be needed are ultimately competent and committed multipliers who act as change agents and not only have the wish but are able to bring about change in the different educational sectors" [11] (p. 821). These emancipatory qualities are linked to competences providing teachers and other educators, as well as their students, with a way of both understanding complexity and transforming their realities while enabling them to make responsible decisions towards more sustainable futures $[9,12]$.

Educators who make Sustainability Education transformational frames their teaching needs within an action-oriented, transformative pedagogy, characterized by elements such as self-directed learning, participation and collaboration, problem orientation, inter- and transdisciplinarity, while carrying out alliances with formal and informal education $[13,14]$. In this regard, different pedagogies in Sustainability Education are highlighted as facilitating these transformations, such as " (.. ) child-centered learning, holistic approaches and head/hands/and heart; rounded education; collaborative and active pedagogies ( ... )." [15] (p. 69). For instance, holistic approaches including innovative aspects related to emotional management have shown to be of great importance in climate change education due to considering feelings such as guilt, hopelessness, helplessness and anger as relevant to make this education more transformational [16]. To explore how these emotional aspects as well as other knowledge, skills and values can lead to such transformations is critical for understanding and enhancing educators' competences in the context of Sustainability Education.

Academics and practitioners, particularly in Europe, have been working on developing frameworks and models of educator competences in Sustainability Education to identify, examine, put in practice and assess such competences. For instance, a recent review [17] on higher education highlights that the UN Economic Commission for Europe (UNECE) framework identifies educators' competences for ESD organized into four pillars of learning (i.e., Learning to Know, Learning to Do, Learning to Live Together and Learning to Be) and three principles (i.e., a Holistic approach, Envisioning change, and Transforming learning systems) [18]. The review concludes that professional development in ESD "should be informed and shaped by these competences [the UNECE competences]" [17] (p. 805). This review also suggests the need of promoting broader changes into educators' thinking and practice to deliver sustainability-related content, as the first step toward their professional development, through critical reflection and more participatory, action and transformative learning pedagogical strategies, for naming some [17]. Another relevant competence model developed to meet the call of the Ministers in the UNECE region to offer curriculum models on sustainability to teacher training centers is the CSCT (Curriculum, Sustainable development, Competences, Teacher training) model created by the Comenius-2 project [19]. This model focuses on the teacher as an individual agent in an educational institution and a member of a particular society. The model identifies ESD competences under three dimensions of competences (i.e., teaching/communicating; reflecting/visioning; networking) and five domains (i.e., knowledge, systems thinking, emotions, values and ethics, action) [19]. Even though the CSCT model offers comprehensively defined competences, there is still a need for clarification on several gaps. For instance, neither the operationalization of the emotional domain that " ( . . ) plays a role as a concomitant in all the other domains" [20] (p. 5069) nor the professionalization process of teachers are well-addressed.

These examples represent only two of the leading competence frameworks for educators used in Sustainability Education, but there is a broader diversity. It thus turns interesting to look at the existing frameworks and models in the scientific literature in a systematic way and analyze how sustainability and competences are understood, characterized and problematized in terms of potential capacity for transformation to contribute to the above mentioned debates surrounding educators' competences in sustainability.

In this line, this literature review aims to identify existing frameworks of competences addressed to teachers and other educators in Sustainability Education and critically examine its relation to transformational and holistic perspectives. To do that, we provide the answer to four research questions:

(a) In which contexts or backgrounds have the analyzed frameworks and models been developed? 
(b) What are the conceptual and pedagogical approaches towards sustainability and competences used to develop these frameworks and models?

(c) Which are the different types of educators' competences included in the frameworks and models, and particularly those addressed to promote transformational perspectives?

(d) Which are the pedagogical strategies applied to develop educators' competences and particularly those addressed to promote transformational practices in Sustainability Education?

\section{Materials and Methods}

\subsection{Data Collection}

The first author conducted a systematic literature review [21] based on a search of academic literature on the frameworks on educators' competences in sustainability in the SCOPUS database. We chose this database mainly due to the broad search engine that this platform offers by including specialized educational databases (e.g., ERIC). A first search was conducted in November 2019 with the following keywords: (TITLE-ABS-KEY ('sustainab*') AND TITLE-ABS-KEY ('education') AND TITLE-ABS-KEY ('framework') AND TITLE-ABS-KEY ('competenc*' OR 'skill') AND TITLE-ABS-KEY ('educator' OR 'teacher'). We got an initial sample of a total of 169 academic publications (after removing replicates). To refine the selection, the first author screened the abstract of each paper according to the following inclusion criteria:

- The article focuses on education for sustainable development and/or Sustainability Education;

- The framework is addressed to educators;

- A framework is used and/or assessed through a training course or another intervention that is analyzed.

Through this first screening, we discarded 131 papers. The remaining 38 articles of the sample were then totally and carefully reviewed to ensure that they fully meet the inclusion criteria. As a result, eight articles fulfilled the inclusion criteria, whereas 30 were discarded. In some cases, for instance, papers were excluded because no framework of sustainability competences was conceived, presented, applied or discussed. In other cases, the articles focused on curriculum changes towards Sustainability Education but without addressing the topic of educators' competences.

We then realized that some key literature was not present in our sample, so we decided to broaden our search terms and include another keyword (i.e., model) in a second search. It was conducted in May 2020 with the following keywords: (TITLE-ABS-KEY ('sustainab*') AND TITLE-ABS-KEY ('education') AND TITLE-ABS-KEY ('model') AND TITLE-ABS-KEY ('competenc' OR 'skill') AND TITLE-ABS-KEY ('educator' OR 'teacher'). We followed the same steps as for the first search and ended up with six new articles in our sample (see Figure 1 for a complete picture on the two searches and Supplementary Materials for discarded papers). Table 1 shows the 14 articles included in our final sample.

The two searches were in English because it is the primary language used in academia worldwide. However, we acknowledge that potentially relevant literature on the topic from non-English sources could have been excluded. We also recognize that using the above mentioned search descriptors might have left behind other perspectives working with EE and ESD to develop sustainability-related competences in educators. 
Table 1. Analyzed academic articles $\left.{ }^{*}\right)$ in the systematic review.

\begin{tabular}{|c|c|c|}
\hline Num. Doc. & Year & Authors, Title. \\
\hline D1 & 2019 & $\begin{array}{l}\text { Vare P., Arro G., de Hamer A., Gobbo G.D., de Vries G., Farioli F., Kadji-Beltran C., Kangur M., Mayer M., Millican R., Nijdam C., Réti M., Zachariou A. } \\
\text { "Devising a competence-based training program for educators of sustainable development: Lessons learned" [22]. }\end{array}$ \\
\hline D2 & 2017 & $\begin{array}{l}\text { Garcia M.R., Junyent M., Fonolleda M. } \\
\text { "How to assess professional competencies in Education for Sustainability?: An approach from a perspective of complexity" [23]. }\end{array}$ \\
\hline D3 & 2017 & $\begin{array}{l}\text { Meyer J., Mader M., Zimmermann F., Çabiri K. } \\
\text { "Training sessions fostering transdisciplinary collaboration for sustainable development: Albania and Kosovo case studies" [24]. }\end{array}$ \\
\hline D4 & 2016 & $\begin{array}{l}\text { Winter J., Cotton D., Warwick P. } \\
\text { The University as a Site of Socialization for Sustainability Education [25]. }\end{array}$ \\
\hline D5 & 2019 & $\begin{array}{l}\text { Albareda-Tiana S., García-González E., Jiménez-Fontana R., Solís-Espallargas C. } \\
\text { "Implementing pedagogical approaches for ESD in initial teacher training at Spanish universities" [26]. }\end{array}$ \\
\hline D6 & 2018 & $\begin{array}{l}\text { Carracedo F.S., Segalàs J., Vidal E., Martin C., Climent J., López D., Cabré J. } \\
\text { "Improving engineering educators' sustainability competencies by using competency maps. The EDINSOST project" [27]. }\end{array}$ \\
\hline D7 & 2017 & $\begin{array}{l}\text { De Kraker J., Dlouhá J., Machackova Henderson L., Kapitulcinová D. } \\
\text { "The European virtual seminar on sustainable development as an opportunity for staff ESD competence development within university curricula" [28]. }\end{array}$ \\
\hline D8 & 2015 & $\begin{array}{l}\text { Cebrián G., Junyent M. } \\
\text { "Competencies in education for sustainable development: Exploring the student teachers' views" [29]. }\end{array}$ \\
\hline D9 & 2013 & $\begin{array}{l}\text { Rauch F., Steiner R. } \\
\text { "Competences for Education for Sustainable Development in Teacher Education" [30]. }\end{array}$ \\
\hline D10 & 2018 & $\begin{array}{l}\text { Albareda-Tiana S., Vidal-Raméntol S., Pujol-Valls M., Fernández-Morilla M. } \\
\text { "Holistic approaches to develop sustainability and research competencies in pre-service teacher training" [31]. }\end{array}$ \\
\hline D11 & 2019 & $\begin{array}{l}\text { Álvarez-García O., García-Escudero L.Á., Salvà-Mut F., Calvo-Sastre A. } \\
\text { “Variables influencing pre-service teacher training in education for sustainable development: A case study of two Spanish universities" [32]. }\end{array}$ \\
\hline D12 & 2014 & $\begin{array}{l}\text { Pipere A., Mičule I. } \\
\text { "Mathematical identity for a sustainable future: An interpretative phenomenological analysis" [33]. }\end{array}$ \\
\hline D13 & 2013 & $\begin{array}{l}\text { Bertschy F., Künzli C., Lehmann M. } \\
\text { "Teachers' competencies for the implementation of educational offers in the field of education for sustainable development" [20]. }\end{array}$ \\
\hline D14 & 2018 & $\begin{array}{l}\text { Varela-Losada M., Arias-Correa A., Vega-Marcote P. } \\
\text { "Training teachers committed to climate change mitigation" [34]. }\end{array}$ \\
\hline
\end{tabular}

$\left(^{*}\right)$ The order of the articles corresponds to the order in which they were found in each search: D1-D8 in Nov 2019; D9-D14 in May 2020. See the Reference section for complete references. 


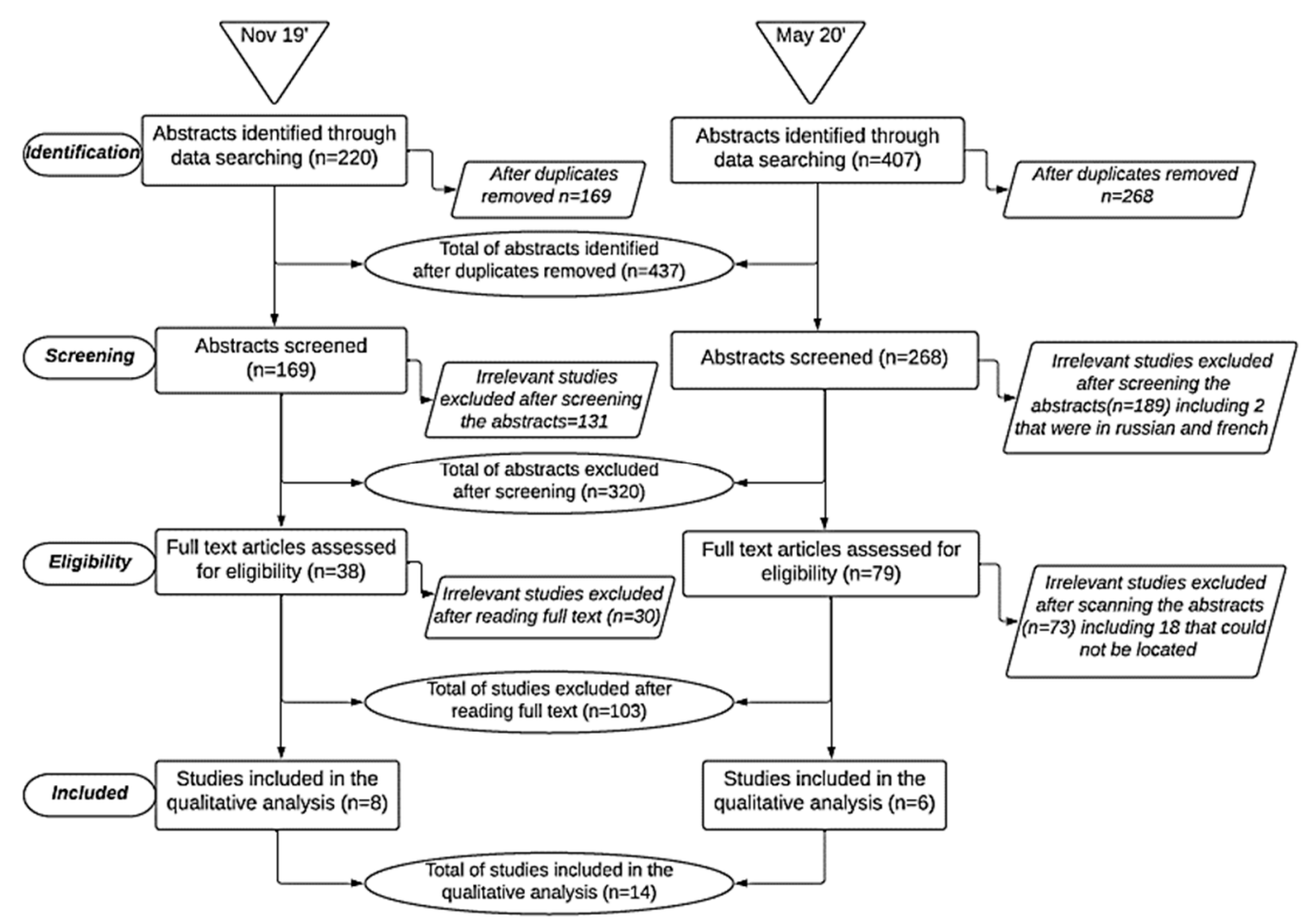

Figure 1. Summary of data collection.

\subsection{Data Analysis}

The first author, with the help of the second author, conducted a conventional content analysis [35] of the selected papers by using pre-defined categories and by relying on the use of the Atlas.ti software (Table 2).

It is relevant to notice that the coding process of the typology of sustainability competences was challenging because each reviewed paper used its own terminology and classification of competences in their frameworks or models. For example, while some articles identified the competences by using the terms employed by UNECE [18] to refer to the pillars of learning (i.e., Learning to Know, Learning to Be, Learning to Live Together, and Learning to Do), other papers related these pillars to the levels of achievement of the proposed competences. For this review and to achieve a common typology of competences, we dealt with this challenge by first identifying the competences from each framework and coding them by using the terminology as showed in the reviewed framework. Then, we conducted a process of re-coding by merging those codes that mentioned the same idea and using the most straightforward and broadest definition, and the corresponding name of the competence for the resulting code, e.g., Criticality and Critical Thinking were coded as Critical Thinking.

Further, and to enrich the analysis, we relied on the UNECE pillars of learning to establish groups of competences since each pillar can represent a different learning experience that goes from knowing to doing [18]. We grouped most of the coded competences into three major groups corresponding to three UNECE pillars: (1) Learning to Know (LtK), (2) Learning to Be (LtB), and (3) Learning to Do $(\mathrm{LtD})$. Following previous studies [22], the UNECE pillar of Learning to Live Together was considered as a competence and included, as other remaining competences, into one of the following bridging groups of competences: (i) Know/Be (K/B) and (ii) Be/Do (B/D). We conceived these bridging groups as those including hybrid competences that make possible the transition between two major groups or learning experiences. Table 3 shows the definitions of each group. 
Table 2. Codes names and description.

\begin{tabular}{ll}
\hline \multicolumn{1}{c}{ Code } & \multicolumn{1}{c}{ Description } \\
\hline General background & $\begin{array}{l}\text { Contextual or background characteristics of the reviewed studies, including country, level of education, } \\
\text { participant's description and research objectives }\end{array}$ \\
\hline $\begin{array}{l}\text { Conceptual and pedagogical approaches to } \\
\text { sustainability and competences }\end{array}$ & $\begin{array}{l}\text { Adopted perspectives towards the concepts of sustainability and competences within the framework or } \\
\text { model, including if these are conceived as transformational or not }\end{array}$ \\
\hline Typology of sustainability competences & Identified types of competences included in the framework or model \\
\hline $\begin{array}{l}\text { Pedagogical strategies applied to develop } \\
\text { educators' competences in sustainability }\end{array}$ & $\begin{array}{l}\text { Pedagogical methods and activities developed when implementing and/or testing the framework or } \\
\text { model on educators' competences in sustainability }\end{array}$ \\
\hline
\end{tabular}

Table 3. Competences groups presented as a learning experience process.

\begin{tabular}{|c|c|c|c|}
\hline UNECE Pillar Group & Definition & Bridging Group & Definition \\
\hline Learning to Know (LtK) & $\begin{array}{l}\text { "A way of thinking (The educator understands ... ) Conceptual, factual } \\
\text { and action-related knowledge. Need for assimilation of the interconnectivity } \\
\text { between the individual, society and nature both locally and globally" [18,19] }\end{array}$ & Know/Be(K/B) & $\begin{array}{l}\text { Hybrid competences representing a } \\
\text { transition between Learning to } \\
\text { Know (LtK) and Learning to Be (LtB) }\end{array}$ \\
\hline Learning to $\mathrm{Be}(\mathrm{LtB})$ & $\begin{array}{l}\text { "A way of feeling (The educator is a person for whom ... ) Thinking, } \\
\text { reflecting, weighing and taking decisions and acting are in dissociable from } \\
\text { emotions. Emotional competency and the development of personal } \\
\text { attributes and abilities to act independently and responsibly are } \\
\text { indispensable for SD" [18,19] }\end{array}$ & $\mathrm{Be} / \mathrm{Do}(\mathrm{B} / \mathrm{D})$ & $\begin{array}{l}\text { Hybrid competences representing a } \\
\text { transition between Learning to Be } \\
\text { (LtB) and Learning to Do (LtD) }\end{array}$ \\
\hline Learning to Do (LtD) & $\begin{array}{l}\text { "A way of acting (The educator is capable of ... ) Developing practical } \\
\text { skills and acting in relation to ESD It is the process in which all the other } \\
\text { competencies from the other domains combine in meaningful creations, } \\
\text { participation and cooperation The individual accepts freedom as } \\
\text { responsibility, coexistence as a model for moving towards democracy and } \\
\text { action as a vehicle for social, environmental and economic } \\
\text { transformation" }[18,19]\end{array}$ & & \\
\hline
\end{tabular}




\section{Results}

\subsection{General Background of the Reviewed Documents}

The studies reviewed were all conducted in European countries: UK (D1, D4), Cyprus (D1), Italy (D1), Hungary (D1), The Netherlands (D1, D7), Estonia (D1), Spain (D2, D5, D6, D8, D10, D11, D14) Czech Republic (D7), Austria (D9), Latvia (D12) and Switzerland (D13). Most of them were developed within formal education contexts, including teacher training institutes (D1, D3-D6, D8-D11, D14) while the rest was conducted in informal educational settings such as learning camps (D1, D2, D7). Participants were educators in basic education (D1, D5, D8, D12, D13) and university level educators (D1, D3, D4, D6, D7, D9-D11, D14). One study did not report the level of education (D2).

Table 4 shows the frameworks and models reported in selected articles as well as the main characteristics of the projects through which they were developed. In some cases, frameworks such as UNECE [18] and CSCT [19] were used as a guide to developing their own frameworks, whereas in other cases these main frameworks were directly applied without changes. Another guiding framework was the key competences in sustainability model by Wiek et al. [36], which was first designed as a global model of converging a set of key competences to guide the design, teaching and assessment of programs and courses in sustainability science.

Differently, some other studies employed frameworks explicitly created for different research purposes. It was the case of the EDINSOST framework [31] designed by a Spanish project to define a sustainability competence map for different university degrees, to validate a variety of didactic strategies and to assess the training needs and sustainability competence levels among teachers and students. The framework named ESD-specific professional action competency of teachers in Kindergarten and Primary School [20] was also purposely developed by a research project, in Switzerland, to serve as a basis for the development of further education offers and coach for advanced professionalization of teachers in ESD.

Finally, we also found a study developing its own framework but using results and findings from previous projects on teachers' professionalization in environmental education. The model of environmental competencies for pre-service teachers, based on components of environmental literacy [32], was designed by using projects developed by the North American Association of Environmental Education [37], such as the Standards for the Initial Preparation of Environmental [38], Guidelines for the Preparation and Professional Development of Environmental Educators [39] and The Excellence in Environmental Education Guidelines for Learning K-12 [37]. 
Table 4. Frameworks and models used in the reviewed papers and related projects.

\begin{tabular}{|c|c|}
\hline $\begin{array}{l}\text { Frameworks or Models Used for } \\
\text { Guidance or Direct Implementation }\end{array}$ & Reviewed Study, Specific Project Name, Territory and Research Focus \\
\hline $\begin{array}{l}\text { UNECE-ESD Educators' Competences } \\
\text { Framework [17] }\end{array}$ & $\begin{array}{l}\text { D1. EU Project A Rounder Sense of Purpose (RSP). } \\
\text { - } \quad \text { Based on: UNECE-ESD educators' competences framework [18]. } \\
\text { - } \quad \text { Research focus: Framework design and training courses that assessed the competences. } \\
\text { D2. Spanish project Education for sustainability from the perspective of Complexity (CESC). } \\
\text { - } \quad \text { Based on Competencies for ESD teachers (CSCT) [19] and UNECE-ESD educators' competences framework [18]. } \\
\text { - } \quad \text { Research Focus: Framework design. } \\
\text { D3. Albania and Kosovo project Connecting Science-Society collaboration for sustainability Innovation (ConSus). } \\
\text { - Based on: UNECE-ESD educators' competences framework [18] and key competences in ESD by Wiek et al. [36] model. } \\
\text { - } \quad \text { Research focus: Training that assessed competences by using existing frameworks. } \\
\text { D4. Not a research project reported-UK } \\
\text { - Based on: UNECE-ESD educators' competences framework [18]. } \\
\text { - } \quad \text { Research focus: Training that assessed adapted competences from an existing framework. } \\
\text { D7. Not a research project reported-European. } \\
\text { - } \quad \text { Based on: UNECE-ESD educators' competences framework [18]. } \\
\text { - Training that assessed adapted competences from an existing framework. } \\
\text { D12. Not a research project reported-Latvia. } \\
\text { - } \quad \text { Based on: UNECE-ESD educators' competences framework [18]. } \\
\text { - Research focus: Analysis of the relation between competences for educators in ESD of an existing framework and educators' identity } \\
\text { (mathematics teaching). } \\
\text { D14. Not a research project reported } \\
\text { - Based on: UNECE-ESD educators' competences framework [18] and key competences in ESD by Wiek et al. [36] model. } \\
\text { - } \quad \text { Research focus: Training that assessed adapted competences from an existing framework. }\end{array}$ \\
\hline Competencies for ESD Teachers (CSCT) [18] & $\begin{array}{l}\text { D2. Spanish project Education for sustainability from the perspective of Complexity (CESC). } \\
\text { - } \quad \text { Based on Competencies for ESD teachers (CSCT) [19] and UNECE-ESD educators' competences framework [18]. } \\
\text { - } \quad \text { Research Focus: Framework design. } \\
\text { D9. EU project Competencies for ESD teachers (CSCT) [19]. } \\
\text { - } \quad \text { KOM-BiNE Competency model [30]. } \\
\text { - Research focus: Framework design and training that assessed the competences. }\end{array}$ \\
\hline
\end{tabular}


Table 4. Cont.

\begin{tabular}{|c|c|}
\hline $\begin{array}{l}\text { Frameworks or Models Used for } \\
\text { Guidance or Direct Implementation }\end{array}$ & Reviewed Study, Specific Project Name, Territory and Research Focus \\
\hline Key Competences in Sustainability by Wiek [35] & $\begin{array}{l}\text { D3. Albania and Kosovo project Connecting Science-Society collaboration for sustainability Innovation (ConSus). } \\
\text { - Based on: UNECE-ESD educators' competences framework [18] and key competences in sustainability by Wiek et al. [36] model. } \\
\text { - Research focus: Training that assessed competences using existing frameworks. } \\
\text { D14. Not a research project reported. } \\
\text { - Based on: UNECE-ESD educators' competences framework [18] and key competences in ESD by Wiek et al. [36] model. } \\
\text { - } \quad \text { Research focus: Training that assessed adapted competences from an existing framework. }\end{array}$ \\
\hline EDINSOST [25] & $\begin{array}{l}\text { D5. Spanish project Education and Social Innovation for Sustainability (EDINSOST). } \\
\text { - } \quad \text { Research focus: Training that assessed adapted competences from an existing framework. } \\
\text { D6. Spanish project Education and Social Innovation for Sustainability (EDINSOST). } \\
\text { - } \quad \text { EDINSOST framework based but adapted to engineering programs. } \\
\text { - } \quad \text { Research focus: Framework design. } \\
\text { D10. Spanish project Education and Social Innovation for Sustainability (EDINSOST). } \\
\text { - } \quad \text { EDINSOST framework based but adapted to all university level. } \\
\text { - } \quad \text { Research focus: Training that assessed adapted competences from an existing framework. }\end{array}$ \\
\hline $\begin{array}{l}\text { ESD-Specific Professional Action Competency of } \\
\text { Teachers in Kindergarten and Primary School [19] }\end{array}$ & $\begin{array}{l}\text { D13. Switzerland project Learning to help shape the future (ZMiLe -Zukunft mitgestalten lernen-, 2013). } \\
\text { - } \quad \text { Research focus: Analysis of two competences models (CSCT and ECE) and the design of a new framework. }\end{array}$ \\
\hline $\begin{array}{l}\text { Standards for the Initial Preparation of } \\
\text { Environmental Educators [37] } \\
\text { Guidelines for the Preparation and Professional } \\
\text { Development of Environmental Educators [38] } \\
\text { The Excellence in Environmental Education } \\
\text { Guidelines for Learning K-12 [36] }\end{array}$ & $\begin{array}{l}\text { D11. Not a research project reported-Spain. } \\
\text { - Model of environmental competencies for pre-service teachers, based on the considered components of environmental literacy [32]. } \\
\text { - Based on: Standards for the Initial Preparation of Environmental [38], Guidelines for the Preparation and Professional Development of } \\
\text { Environmental Educators [39], The Excellence in Environmental Education Guidelines for Learning K-12 [37]. } \\
\text { - Research focus: Analysis of the link between different personal and educational factors and the acquisition of environmental } \\
\text { competences from a dimensional model. }\end{array}$ \\
\hline
\end{tabular}




\subsection{Conceptual and Pedagogical Approaches behind the Concepts of Sustainability and Competences}

Interestingly, the definition of the term sustainability was not specifically addressed by any of the reviewed papers. We found a similar situation with the concept of Sustainability Education but, in this case, the studies referred to different related terms from which one could infer their understanding. One of them referred to EE as an approach employed in its framework and used it in an exchangeable way with ESD (D14). In contrast, other articles established direct links between ESD and their approaches or frameworks (D1, D4, D7-D13). Thus, generally speaking, selected studies seemed to agree with the global vision of ESD, and often support this approach by relying on UNECE documents that are in line with the ESD concept and other UNESCO reports and European level conferences about education and sustainability.

The definition of ESD, although not explicitly present in all papers, was included in some of them by using different formulas. For instance, one of the studies (D2) referred to the UNESCO's ESD approach that highlights its transformative potential towards changing individual and collective behaviors:

"Education for Sustainable Development has the potential to empower learners to transform themselves and the society they live in by developing knowledge, skills, attitudes, competences and values required for addressing global citizenship and local contextual challenges of the present and the future, such as critical and systemic thinking, analytical problem-solving, creativity, working collaboratively and making decisions in the face of uncertainty, and understanding of the interconnectedness of global challenges and responsibilities emanating from such awareness (UNESCO, 2015, p. 1)" (D2) [23], p.773).

In another case (D9) ESD was mainly understood as a powerful tool for encouraging participation and reflection: "Education for sustainable development does not aim at changing people's lifestyles, but at empowering and encouraging people to participate in designing sustainable development and to critically reflect on their own action in this area (Künzli-David, 2007, p.30)"(D9) [30] (p.14).

By contrast, other studies presented the well-known debates about the different understandings of sustainability within an ESD perspective, its scope and contradictions (D3, D4, D5, D6, D14). Furthermore, in doing this, some of them defended the use of ESD over EE when dealing with educators' competences (D3, D5, D6). In D3, for instance, it is argued that EE is reduced to the natural world while ESD deals with the interaction with the social one:

“ $(\ldots)$ while EE is focusing in preservation of the natural environment and the reduction of human impact, ESD teach awareness, skills, perspectives and values that will guide and motivate people to pursue sustainable livelihood, participate in a democratic society, and live in a sustainable manner (McKeown and Hopkins, 2003)" (D3) [24] (p. 744).

When we looked at the ways that the studies approached the term competences, surprisingly, we found that almost half of the reviewed studies did not define this concept (D2, D4, D6, D10, D12 and D13). Papers reporting definitions included elements such as attitudes, knowledge, values and skills or abilities (D1, D3, D5, D7, D8, D9, D11, and D14).

Regarding the links between sustainability and competences in definitions, just a few articles (D6-D8) integrated into their definition of competence, theoretical elements specifically related to sustainability, for seeing this relationship as a competence itself (sustainability competence) or as the final goal to be pursued (competences towards SD). Few articles explicitly referred to sustainability competences as professional competences (D2, D7, D13). For example, in D13, there was some concern expressed about the understanding of ESD competences for educators under a strict behaviorist approach. This article argued that the professionalization of teachers could not depend on promoting specific behaviors towards sustainable development. In only one paper, sustainability competences were defined as different from generic competences (D1). In this line, we identified two main understandings of the competences for educators in Sustainability Education among the reviewed papers. The first understanding addressed by D4, D6, and D11 conceptualized these competences as those related to generic competences that are not necessarily focused on the role of educators. This understanding was somehow linked to educators or future teachers in Sustainability Education, but overall addressed to 
foster environmental skills or values in a general way, that is, they could also be applied for students or any other societal actor. Some examples:

- D6: "Participation in Community processes that promote sustainability" [27] (p. 6).

- D11: "To engage in individual behavior that is respectful of the environment in everyday life, as well as participating in pro-environment collective actions" [32] (p. 14).

On the other hand, most of the papers (D1-D3, D5, D7-D10, D12-D14) conceptualized sustainability competences as those explicitly considering the role of educators. This understanding explicitly focused on knowledge, values, skills and attitudes needed for the educator in a Sustainability Education context. Some examples:

- D8: "Manage emotions and concerns: promoting reflection on one's own emotions and as a means to reach a deeper understanding of problems and situations". [29] (p. 2771)

- D12: "Facilitate participatory and learner-centered education that develops critical thinking and active citizenship". [33] (p. 20)

In close relation to how educators can put these competences in Sustainability Education into practice, we identified that all of the reviewed papers adopted a socio-constructivist pedagogical perspective using a competence-based approach. In doing this, some referred to a transformative and socially critical pedagogy approach towards sustainability (D3-D10, D14), highlighting, for instance, the importance of linking the academic content to real-life problems to undertake action (D3). Other studies also embraced a holistic approach that related Sustainability Education with inter and transdisciplinary work, as well as complexity and research competences (D1-D3, D5-D7, and D10). Central pedagogical aspects in this regard also included reflection (D12, D14), collaboration (D1, D3, D7, D11 and D14) and participation (D12, D14).

\subsection{Typology of Sustainability Competences Identified from the Frameworks}

We identified a total of 29 educators' competences across the reviewed frameworks and models in Sustainability Education (Table 5). As explained in the Methods section, for our analysis, we included into the same competence type those competences having the same meaning and named by the studies in the same way, as well as those with slightly different names or without a specific name but promoting the same idea. According to the selected three learning moments or experiences represented by the UNECE pillars of learning [18], explained in the data analysis section, we found that most of the competences were related to Learning to Do (LtD,12), followed by Learning to Be (LtB,8). In contrast, only a few were associated with Learning to Know (LtK, 3). The two bridging groups, which included hybrid competences that represent the transition between two of the major groups of competences or learning experiences, also showed notable differences in the number of the competences related to each group since only one competence was included in Know/Be (K/B) and seven in Be/Do (B/D). Interestingly, frameworks defined some competences in broader terms without making an explicit reference to Sustainability Education, such as in the case of Intellectual Development and Scientific Thinking in the LtK group. 
Table 5. Competences name, group and definition, and the studies naming them $\left(^{*}\right)$.

\begin{tabular}{|c|c|c|c|}
\hline Competence Name & Competence Group & Broader Definition Chosen & Study/ies and Original Competence Name \\
\hline Intellectual Development & LtK & Putting emphasis on the intellectual development of students (D8) [29] (p. 2775). & D8-Transversal competencies ${ }^{1}$ \\
\hline Scientific Thinking & LtK & $\begin{array}{l}\text { Explaining and interpreting phenomena scientifically and identifying appropriate } \\
\text { explanations and predictions (D8) [29] (p. 2775) }\end{array}$ & $\begin{array}{l}\text { D4 }^{2} \\
\text { D8-Science education competencies }{ }^{1} \\
\text { D10-Research Comperency }{ }^{1}\end{array}$ \\
\hline Critical Thinking & LtK & $\begin{array}{l}\text { Critical contextualization of knowledge establishing interrelationships between social, } \\
\text { economic and environmental, local and/or global problems (D9) [30] (p. 19) }\end{array}$ & $\begin{array}{l}\text { D1-Criticality }{ }^{1} \\
\text { D2 }^{3} \\
\text { D3 }^{2} \\
\text { D4 }^{2} \\
\text { D5-Sust1 }^{1} \\
\text { D6-C1 }^{1} \\
\text { D7 }^{2} \\
\text { D8 }^{2} \\
\text { D9 }^{2} \\
\text { D10-Sust1 }^{1} \\
\text { D11-EC5 }^{1} \\
\text { D12 }^{2} \\
\text { D13 }^{2} \\
\text { D14 }^{2}\end{array}$ \\
\hline Connections & $\mathrm{K} / \mathrm{B}$ & $\begin{array}{l}\text { To know the main concepts and principles in connection with the Earth as a } \\
\text { biophysical system and in connection with the relationships and interactions between } \\
\text { society and the environment (D11) [32] (p. 4) }\end{array}$ & $\begin{array}{l}\text { D1-Systems }^{1} \\
\text { D2 }^{3} \\
\text { D4 }^{2} \\
\text { D5 }^{2} \\
\text { D8 } \\
\text { D10-SC1 }^{1} \\
\text { D11-EC1/EC2 }^{1} \\
\text { D13 }^{2} \\
\text { D14-Systems Thinking }^{1}\end{array}$ \\
\hline Futures & LtB & $\begin{array}{l}\text { It offers ways of addressing and helping to shape the future [ ... ]. It enables } \\
\text { individuals to recognize relations and possible evolutions between past, present, and } \\
\text { future and envision possible or thinkable futures alternatives and their impact } \\
\text { (D1) [22] (p. 10). }\end{array}$ & $\begin{array}{l}\text { D1 } \\
\text { D8-Future/alternative scenarios visioning } \\
\text { D9 }^{2} \\
\text { D10 } \\
\text { D14 }\end{array}$ \\
\hline Attentiveness & LtB & $\begin{array}{l}\text { This competence relates to knowledge about sustainability issues while emphasizing } \\
\text { the difference between information and understanding. Our pre-existing knowledge } \\
\text { determines how we see the world and what we notice in our environment [... ] The } \\
\text { goal of an educator is to help learners to process new knowledge explicitly and not to } \\
\text { simply be exposed to information about the world (D1) [22] (p. 11). }\end{array}$ & $\begin{array}{l}\text { D1 } \\
\text { D12 } \\
\text { D14 }\end{array}$ \\
\hline
\end{tabular}


Table 5. Cont

\begin{tabular}{|c|c|c|c|}
\hline Competence Name & Competence Group & Broader Definition Chosen & Study/ies and Original Competence Name \\
\hline $\begin{array}{l}\text { Holistic Dimension of } \\
\text { Sustainability }\end{array}$ & LtB & $\begin{array}{l}\text { It takes into account the historical perspective of sustainability, analyzes different } \\
\text { dimensions, promotes creativity and innovation, reflects on new ways (D6) [27] (p. 8) }\end{array}$ & $\begin{array}{l}\text { D3-Holistic approach }{ }^{1} \\
\text { D5 }{ }^{2} \\
\text { D6 }^{3} \\
\text { D10 }^{3}\end{array}$ \\
\hline Transdisciplinary & LtB & $\begin{array}{l}\text { Working towards sustainability calls for the ability to collaborate with a diverse group } \\
\text { of people. Educators are challenged to promote this competence among their learners } \\
\text { and model it by, for example, facilitating school-community collaborations [ ... ] } \\
\text { (D1) [22] (p. 11) }\end{array}$ & $\begin{array}{l}\mathrm{D}^{3} \\
\mathrm{D}^{2} \\
\text { D8-Transversal competencies }\end{array}$ \\
\hline Uncertainty & LtB & $\begin{array}{l}\text { The educator works with others from a perspective of uncertainty as an ethical, social } \\
\text { and political attitudes to seek social construction and with an open view of the future } \\
\text { (D2) [23] (p. 777). }\end{array}$ & $\mathrm{D} 2^{3}$ \\
\hline Emotions Management & LtB & $\begin{array}{l}\text { To manage emotions and concerns: promoting reflection on one's own emotions as a } \\
\text { means to reach a deeper understanding of problems and situations (D8) [29] (p. 2771). }\end{array}$ & $\begin{array}{l}\text { D1-Empathy }{ }^{1} \\
\text { D8-Manage emotions and concerns }{ }^{1} \\
\text { D9 }^{2} \\
\text { D10 }^{2} \\
\text { D13 }^{2} \\
\text { D14 }^{2}\end{array}$ \\
\hline Learner centered & LtB & $\begin{array}{l}\text { To provide student-centered education to promote the development of critical } \\
\text { thinking, active citizenship and participation (D14) [34] (p.313) }\end{array}$ & $\begin{array}{l}\mathrm{D}^{2} \\
\mathrm{D}^{2} 2^{2} \\
\mathrm{D}^{2} 4^{2}\end{array}$ \\
\hline Belong to nature & LtB & Fostering in students a sense of belonging to the environment (D8) [29] (p. 2775). & D8-ESD competencies ${ }^{1}$ \\
\hline Envisioning change & $\mathrm{B} / \mathrm{D}$ & $\begin{array}{l}\text { Meaning the time perspective for change toward sustainable development }(\ldots) \\
\text { understanding the reasons for unsustainable development, its actual development } \\
\text { and also its future prospective. It also refers to motivation for learning out of those } \\
\text { experiences and raising awareness for the need of developing shared visions among } \\
\text { the different perspectives of scientific and societal stakeholders (D3) [24] (p. 749). }\end{array}$ & $\begin{array}{l}\text { D }^{3} \\
\text { D9-Visioning }^{1} \\
\text { D12 }^{2}\end{array}$ \\
\hline Learning to live together & $\mathrm{B} / \mathrm{D}$ & $\begin{array}{l}\text { A way of coexisting. The educator works with others in such a way that ( } \ldots \text { ) norms, } \\
\text { values, attitudes, beliefs and assumptions guide our perceptions, our thinking and } \\
\text { our decisions and actions. Cooperation, interdependence, pluralism, understanding, } \\
\text { equality, freedom, uncertainty as an ethical attitude all foster the move towards ESD } \\
\text { (D2) [23] (p. 777). }\end{array}$ & $\begin{array}{l}\text { D2 }{ }^{3} \\
\text { D3 }^{3} \\
\text { D5-Sust }^{3}{ }^{1} \\
\text { D7 } \\
\text { D10-SC } 3^{1} \\
\text { D11-EC 3 } 3^{1} \\
\text { D14+ }\end{array}$ \\
\hline
\end{tabular}


Table 5. Cont

\begin{tabular}{|c|c|c|c|}
\hline Competence Name & Competence Group & Broader Definition Chosen & Study/ies and Original Competence Name \\
\hline Dialogue & $\mathrm{B} / \mathrm{D}$ & $\begin{array}{l}\text { That which facilitates acceptance and approaches multiple ways of understanding the } \\
\text { world and promotes the exchange of ideas, cooperation, negotiation and } \\
\text { understanding (D2) [23] (p. 776). }\end{array}$ & $\begin{array}{l}\text { D2 } \\
\text { D7 } \\
\text { D8-Establish a dialogue between disciplines } \\
\text { D14 }\end{array}$ \\
\hline Networking & $\mathrm{B} / \mathrm{D}$ & $\begin{array}{l}\text { As one requisite competence, ESD teachers must be able to organize and moderate } \\
\text { cooperation with non-formal educational institutions, in order to arrange for learning } \\
\text { opportunities for pupils in and with extramural institutions (D9) [30] (p. 21). }\end{array}$ & $\begin{array}{l}\mathrm{D} 9^{2} \\
\mathrm{D}^{2} 0^{2}\end{array}$ \\
\hline Communicating & $\mathrm{B} / \mathrm{D}$ & $\begin{array}{l}\text { Ability without which all other areas are inconceivable. While communication is a } \\
\text { sine qua non for planning, organizing and networking, it is not a matter of course for } \\
\text { the more individual areas (D9) [30] (p. 20). }\end{array}$ & $\begin{array}{l}\text { D9 }{ }^{3} \\
\text { D10-Research Comperency }{ }^{1}\end{array}$ \\
\hline Achieving Transformation & LtD & $\begin{array}{l}\text { Related to transformation approaches in education, pedagogy and for educators and } \\
\text { education systems in all the levels (Lk, Llt, Lb, Ld) (D3) [24] (p. 740). }\end{array}$ & $\begin{array}{l}\text { D1-Action } \\
{ }^{1} \\
\text { D3 } \\
\text { D8 } \\
2 \\
\text { D12 }^{2} \\
\text { D13 }^{2} \\
\text { D14 }^{2}\end{array}$ \\
\hline Healthy Lifestyles & LtD & $\begin{array}{l}\text { Developing habits and attitudes favorable to the promotion of healthy lifestyles, at } \\
\text { the personal and community level (D8) [29] (p. 2775). }\end{array}$ & D8-Transversal competencies ${ }^{1}$ \\
\hline Economic Dimension & LtD & $\begin{array}{l}\text { [The teacher] is capable of successfully carrying out the economic management } \\
\text { (amortizations, fixed costs, variable costs, planning budgets, detect deviation, make a } \\
\text { business plan) of a project (D6) [27] (p. 10). }\end{array}$ & $\mathrm{D}^{3}$ \\
\hline Creativity & LtD & $\begin{array}{l}\text { That which generates imaginative processes that involve a specific result, be that an } \\
\text { action, idea or object. Enables the creation of spaces for shared learning and promotes } \\
\text { the visualization of sustainability scenarios (D2) [23] (p. 776). }\end{array}$ & 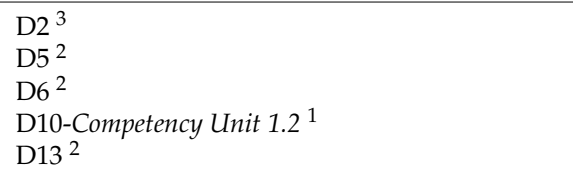 \\
\hline Innovation & LtD & $\begin{array}{l}\text { Educators will need to reflect on their practice and renew their methods as they adapt } \\
\text { to new situations while understanding that "new" is not necessarily better (D1) [22] } \\
\text { (p. 11). }\end{array}$ & $\begin{array}{l}\mathrm{D} 1^{3} \\
\mathrm{D} 2^{3} \\
\mathrm{D} 4^{2} \\
\mathrm{D}^{2} \\
\text { D8-Establish a dialogue between disciplines } 1\end{array}$ \\
\hline
\end{tabular}


Table 5. Cont

\begin{tabular}{|c|c|c|c|}
\hline Competence Name & Competence Group & Broader Definition Chosen & Study/ies and Original Competence Name \\
\hline Responsibility & LtD & $\begin{array}{l}\text { [ ... ] the educator of ESD will have a range of tools, through which to develop their } \\
\text { learners' abilities to act responsibly. In this way, they will encourage long-term } \\
\text { thinking about what kind of human beings we want to be and what kind of world we } \\
\text { want to live in (D1) [22] (p. 11). }\end{array}$ & $\begin{array}{l}\mathrm{D}^{3} \\
\mathrm{D}^{2} \\
\mathrm{D}^{2} \\
\text { D8-Transversal competencies }\end{array}$ \\
\hline Social Dimension & LtD & $\begin{array}{l}\text { [The teacher] takes into account the social impact (social justice, equity, diversity, } \\
\text { transparency, gender perspective, needs of the most vulnerable groups, strategies } \\
\text { against corruption) of his/her work (D6) [27] (p. 10). }\end{array}$ & $\mathrm{D}^{3}$ \\
\hline Participation in Community & LtD & Participation in community processes that promote sustainability (D6) [27] (p. 6) & $\begin{array}{l}\text { D1-Participation }{ }^{1} \\
\text { D5-Sust } 3^{1} \\
\text { D6-C3 }{ }^{1} \\
\text { D8-Science education competencies }{ }^{1} \\
\text { D10-Sust } 3^{1} \\
\text { D11-EC6 }{ }^{1} \\
\text { D12 }^{2} \\
\text { D14-Interpersonal competence }\end{array}$ \\
\hline Environmental Dimension & LtD & $\begin{array}{l}\text { Takes into account the environmental impact (reuse, reduction, recycling, } \\
\text { minimization of the natural resources and residues, the concept of ecological } \\
\text { footprint) of his/her work (D6) [27] (p. 10). }\end{array}$ & $\mathrm{D}^{3}$ \\
\hline Applying Sustainability Values & LtD & $\begin{array}{l}\text { To apply ethical principles related to sustainability values in personal and } \\
\text { professional behavior (D10) [31] (p. 2). }\end{array}$ & $\begin{array}{l}\text { D6-C4 }{ }^{1} \\
\text { D9 }^{2} \\
\text { D10-Sust } 4^{1} \\
\text { D11-EC3 and EC5 }{ }^{1} \\
\text { D13-ESD competence aspect motivation and volition }{ }^{1} \\
\text { D14-Normative competence }{ }^{1}\end{array}$ \\
\hline Sustainable Use of Resources & LtD & $\begin{array}{l}\text { Sustainable use of resources and prevention of negative impacts on the natural and } \\
\text { social environment (D6) [27] (p. 6). }\end{array}$ & $\begin{array}{l}\text { D6-C2 }{ }^{1} \\
\text { D10-Sust } 2^{1}\end{array}$ \\
\hline Design Educational Activities & LtD & $\begin{array}{l}\text { Ability to choose possible teaching topics and to evaluate their aptitudes for ESD } \\
\text { regarding their economic, ecological, social and cultural design as well as their } \\
\text { relevance for sustainability (pedagogical content knowledge) (D13) [20] (p. 5076). }\end{array}$ & $\begin{array}{l}\text { D10 } \\
\text { D13-ESD competence aspect knowledge and ability }{ }^{1}\end{array}$ \\
\hline
\end{tabular}

$\left.{ }^{*}\right)$ Meaning of the superscript numbers next to the studies: ${ }^{1}$ The competence was named in a slightly different way, but the main idea agrees with the broader definition of the competence, there is an explicit indication of the original name. ${ }^{2}$ The competence was not named under any particular name, but the main idea agrees with the broader definition of the competence. ${ }^{3}$ The competence was exactly named as the typology offered. 
The most commonly mentioned competence in the reviewed frameworks and models was Critical Thinking, which belonged to the LtK group and was found in the 14 studies (100\%). Connections, which was classified as a bridging competence in the K/B group, was found in nine frameworks $(64 \%)$, followed by Participation in Community, from the LtD group, mentioned by eight frameworks (57\%) and the bridging competence of Learning to Live Together by seven papers (50\%). Furthermore, Emotions Management (42\%) and Futures (35\%) from the LtB group and Achieving Transformation $(42 \%)$ belonging to the group of LtD relatively stand out. By contrast, we found several competences in different groups that were only mentioned by one study $(7 \%)$, most of them referring to specific aspects of the UNECE pillar of LtD [17] and included in the framework of D6, such as Economic Dimension, Social Dimension and Environmental Dimension. Figure 2 offers a visual representation of the identified competences across the learning process and their quantitative presence in the reviewed studies. As mentioned above, four competences were included in most of the frameworks reviewed (between $50 \%$ and $100 \%$ of the 14 studies reviewed). Nine competences were cited by 4 to 6 articles (between $30 \%$ and $49 \%$ of the documents), while 16 competences were less represented since they were only found in one, two or three studies (between $7 \%$ and $29 \%$ of the total).

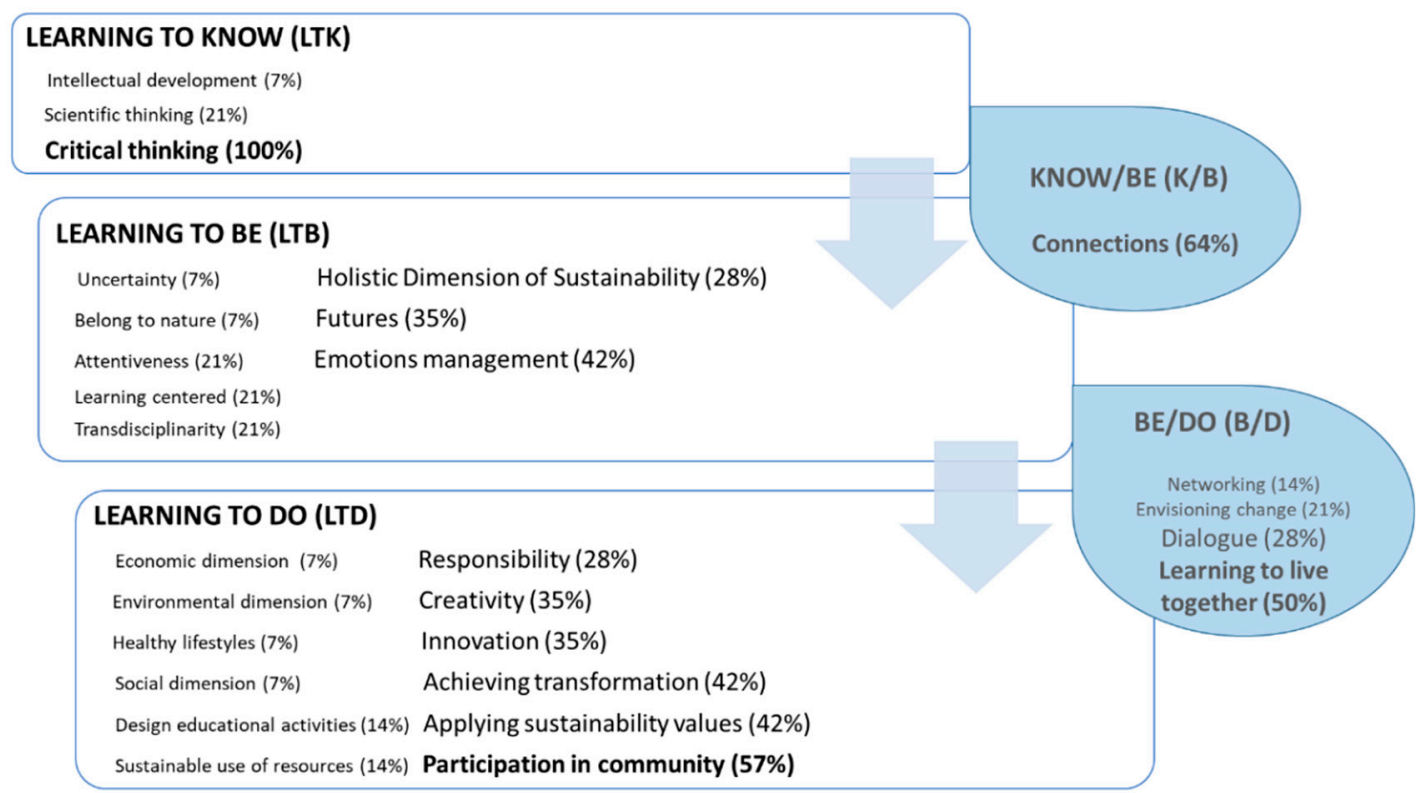

Figure 2. Typology of competences and percentage of their presence in the reviewed frameworks, by groups of competences.

In terms of transformative learning, it is of special interest to highlight that the Achieving Transformation competence was understood as the educator's ability to helping learners to realize and exercise their agency for taking action (D1, D12) [22,33], but also addressed issues beyond the individual level. For instance, this competence aiming to achieve transformation was also understood as the ability of making proposals to make human activities more sustainable by analyzing their impact (D8) [29] or raising awareness of the need for changes in teaching methods (D14) [34].

When looking at the different types of competences included in the reviewed frameworks and models, we often found that replicability was a topic of concern and discussion. Some studies highlighted that the framework presented, and consequently, the competences included, had been used by different institutions or in other scenarios beyond the original ones (D1 and D2). Furthermore, they raised the concern that the additional impact of these frameworks will depend on the institutional (research-teaching) and governmental willingness to adopt and implement them (D1, D3, D5, D7). This concern relates to the challenge of how each competence will be understood, and consequently implemented, by each institution and teacher (D1). Additionally, in the case of those frameworks 
resulting from a crossed analysis between competences in Sustainability Education and other topics such as competences for mathematics educators (D12), complexity (D2), or research (D10), such integrative approaches were seen as a positive innovation but also required further research to be fully implemented in the field of Sustainability Education.

\subsection{Pedagogical Strategies Applied to Develop Educators' Competences in Sustainability Education.}

More than half of the studies (64\%) included and reflected about the pedagogical methods and activities that could be employed to promote the educators' competences in Sustainability Education addressed in their frameworks (D1, D3-D5, D7-D10, D14). These pedagogical strategies were not explicitly linked to the promotion of any particular competence, but they could be associated with the three main UNECE pillars of learning representing learning experiences [17]. We present some relevant examples in what follows:

Learning to Know: A variety of pedagogical activities mainly addressed Critical Thinking and Scientific Thinking competences, ranging from peer discussions to planning a research project. For instance, peer discussions were implemented primarily to let educators know and reflect on the history of the field of Sustainability Education while exploring its different paradigms from a critical perspective (D4). Holding periodic peer discussions together with group analysis procedures and the planning and design of a research process through a series of guiding tasks and questions were also highlighted as useful to foster these competences among educators (D5, D10).

Learning to Be: Transdisciplinarity and Dialogue, for instance, were promoted through developing briefs for teaching sustainability by working in interdisciplinary teams of educators (D4). An artistic, pedagogical proposal was applied in the case of the competence Apply sustainability values for which role plays were used because of the potential of this approach to work with values, and particularly sustainability values (D14). By contrast, finding pedagogical activities to address the competence of Holistic Dimension of Sustainability effectively was challenging (D1, D6-D8). Exceptionally, it was highlighted that working in small groups to solve real problems was crucial for developing this competence (D10). However, another study suggested that the implemented pedagogical activities to promote a holistic view of the system were not successful because teachers conferred more importance to Learn to know related competences than to those competences working on attitudes, values and emotions from the LtB group (D8).

Learning to Do: Pedagogical strategies promoting competences related to Participation in Community and Decisiveness included, for instance, the provision of an authentic and real-world task in the classroom (D1), excursions with municipal bodies and other local stakeholders outside school (D3), and research projects on real sustainability problems which findings were further presented in congresses through posters. Additionally, within these projects, other actions were implemented to improve these competences among educators such as their involvement in the development of blogs, lapbooks, models of ecological information for schools, or compilations of activities in parks. In some cases, these pedagogical actions and strategies were done in international teams of educators facilitated by the use of ICT (D7). These active-learning strategies were found as useful in addressing real-world problems. Still, it was argued that further research should consider socio-demographic aspects when designing the pedagogical activities focused on LtD competences to contextualize them and increase their effectiveness in terms of transformation (D5).

It is worthy to notice that, in some cases, these pedagogical interventions approached the educator as a student in the hope that through experiencing and doing the activities they could replicate them in their role as educators (D3, D4, D8, D9, D10). However, these interventions did not include spaces for reflection on how the educators could relate the competences they were acquiring as students with their role as educators. Training participants could even have had problems to differentiate and recognize that the competences to be developed were for them as educators and not for their students (D1). Only in several cases, training participants had the opportunity to reflect on their role as educators when improving their competences through the activities (D1, D5, D7, D14). 
Finally, in some cases, the analyzed pedagogical interventions led educators to reflect on their role in influencing pupils' behavior and how to improve their practice towards more action-based and transformational perspectives (D5, D7, D9, D12, D14). See, for instance, the following observations and testimonies from two studies:

"it is not about training children to adopt a behavior which has been recognized as correct, but about supporting them in taking decisions based on their own judgment". (D9) [30] (p. 19)

“( ... ) future teachers highlighted the importance of using motivational methodologies based on globalized approaches which favor interaction and participation, and where students go from being spectators to becoming actors"' (D14) [34] (p. 316).

\section{Discussion}

Based on our findings, we identify three relevant topics for discussion to advance in the understanding of the development of competence frameworks and models addressed to educators in Sustainability Education with a focus on fostering transformation. These three topics are (1) the methodological limitations of our systematic review approach; (2) the understanding of the concepts of sustainability and competences as used by the analyzed competence frameworks and their implications in terms of building capacity for promoting transformation, and (3) the practical and transformative impact of the pedagogical strategies applied in the reviewed studies to foster educators' competences.

First, all the studies included in our sample through a systematic review process of academic literature came from the European arena and most of them were developed in formal education and particularly in higher education contexts. This result might suggest that the specific research approach towards competences exploring how models and frameworks are conceptualized and implemented could have been mainly developed by academics working in European institutions. Still, some reviewed studies relied on North-American models such as the one from Wiek et al. [36] and the guidelines produced by the North American Association for Environmental Education (NAAEE) [37], which also highlights the relevance of the research produced in this world region. These results are consistent with the general Western dominance in this research area within the field of Sustainability Education that has been already found by previous studies [40]. However, the observed geographical trend could also be due to limitations in our research design. As mentioned earlier, our search was guided by a set of pre-established keywords, so some other studies may have been included in our sample if we had added other synonyms to our search, such as "guideline". Besides, since we conducted the search in English and within SCOPUS, we excluded academic literature published in other languages and through other databases from our review (e.g., Latin-American or French-speaking African countries). Thus, to enrich our understanding about how educators' competences are being conceived in the field of Sustainability Education worldwide, further research could address these caveats to complement and discuss our findings on the competences addressed in the frameworks reviewed, the pedagogical strategies applied to promote them and the implications for fostering transformation.

Second, concerning the initial EE/ESD debates about the different understandings of the sustainability concept in terms of its relation to development and growth [8], it seems that the reviewed body of literature about competence frameworks for educators has overcome this debate. When looking at our findings in terms of the types of competences for educators in Sustainability Education, only one study explicitly includes in its framework a competence focused on economic growth and development (D6). Sustainability then seems to be conceived by the authors of these competence frameworks as it is in the "post-sustainability" debates [10]: as an empty signifier that let us opening new spaces for critical discussion and transformation and a process that permanently is in-becoming rather than a close concept mainly related to growth. Accordingly, the reviewed frameworks have relied on the ESD approach by understanding sustainability as "( ... ) both an explorative process and a broad direction" [41] (p. 512). 
Beyond the understanding of sustainability, the transformative potential of the reviewed frameworks is also related to the way they conceive and theoretically address educator competences in Sustainability Education. Our results suggest that a limited theoretical foundation in this last regard might exist since only half of the reviewed studies include a definition of the concept of competence. This apparent lack of theoretical foundation can also be associated with the fact that some of them use Wiek et al.'s framework of competences [36] as a reference, although this has been developed for students and thus it does not describes educators' competences. It might lead to some bias when applied to educators since the way that competences in Sustainability Education are conceived for students should differ from the case of educators. Furthermore, some frameworks consider theoretical and pedagogical approaches as competences, such as Learner Centered, or include competences not explicitly related to Sustainability Education, such as Scientific Thinking, which might lead to conceptual confusion and misguide educators' practice. We thus wonder whether it is theoretically and practically suitable to include these types of competences in a framework. Different answers will evolve from the two main conceptualizations of sustainability competences showed in our results: one that specifically addresses the role of educators and another that relates these competences to generic ones that could also apply for students or other actors. Previous research [20] has suggested that frameworks should emphasize those competences linked to the professionalization of educators, which follows the first conceptualization. This approach is of special consideration for curriculum developers in pre-service training institutions who pursue to train future teachers by using the existing frameworks and models found in this review. It is not the same to prepare educators for enhancing their competences in sustainability issues (i.e., teaching future teachers to recycle) than training for improving their competences in Sustainability Education (i.e., teaching future teachers to know how to handle contradictions within sustainable dilemmas exposed in a class). In this sense, further research can comparatively analyze the transformational impact of each approach in terms of educators' development of competences in Sustainability Education.

Further, our results show that those competences more present across frameworks particularly address knowledge, skills, values and attitudes that have been identified as those that educators need to face current sustainability challenges from a critical and transformative perspective $[4,9,11]$, such as Critical Thinking, Connections and Participation in Community. However, the fact that the most frequently addressed competences in the reviewed frameworks belong to the group of LtD might be a sign of applying the competence-based approach with an excess of pragmatism and reductionism [5]. It is argued that other sets of competences are also needed for fostering transformation [42], as the ones in the LtB group. For instance, handle with controversial topics in Sustainability Education involves knowing how to embrace and deal with related values and attitudes, which requires the mastery of competences such as Emotional management and Uncertainty. The little attention that the reviewed frameworks put on these and other LtB competences in comparison to the LtD group of competences matches with previews findings from case-studies on climate change education [16], as well as with the perceptions of the teachers participating in one of the reviewed studies (D7).

Lastly, it turns interesting to discuss that the most varied pedagogical strategies put into practice to implement the reviewed competence frameworks are also the ones related to the LtD group of competences. Indeed, it has been argued that educators aiming to make Sustainability Education transformational need to engage in an action-oriented pedagogy, while embracing self-directed learning, orientation to the problem, inter and transdisciplinary, participation and collaboration [13]. As mentioned above, some of these key aspects for transformation are also related to the LtB group, but this group of competences has also received less attention in terms of the pedagogical strategies needed to promote them. In a way, all competences and levels of learning seem to be key to achieve transformative learning processes, considering that transformative learning entails conscious changes in attitudes, values and behaviors [43]. In this sense it has been argued that transformative learning acts at the deepest level of learning, where the first one involves "doing things better" (external objective world), the second level refers to "doing better things" (ethics, values, beliefs), and the deepest 
one makes the consciousness to evolve into "seeing things differently" (epistemic dimension) [44]. This view is in line with transformative sustainability education (TSE) pedagogical strategies that focus on participatory, place-based approaches to promote deep relational and emotional changes in consciousness about and connections between the self and the surrounding world [45]. Thus, a challenge is to explore effective pedagogical approaches to improve educators' competences related to complex learning processes involving, for instance, emotional aspects, so these pedagogical strategies can create the space for environmental values to evolve [46]. This endeavor requires training educators in promoting spaces for sharing experiences, emotional openness and resonant understanding [47]; in sum, putting emphasis, following the "wild pedagogies" approach, on emotions and the fluctuant reality [15]. Future research should consider analyzing the impact of training courses fostering these emotional competences in terms of their contribution to developing educators' emancipatory qualities with transformative potential [9].

\section{Conclusions}

The main research objective of this review is to identify and analyze frameworks and models of competences for educators in Sustainability Education in the scientific literature and to examine their relation to transformational perspectives. Our findings have provided answers to the research questions posed regarding this objective while recognizing methodological limitations. All of the 14 reviewed papers are developed in the European context, although North-American perspectives influence some of them and are in line with ESD and competence-based approaches. However, the theoretical foundations of how these papers tackle the concepts of sustainability and competences are poorly developed. Our findings also show that reviewed frameworks conceptualize sustainability competences by explicitly addressing the role of educators or, in contrast, by relating these competences to generic ones, which might have practical implications and shape the transformational potential of the frameworks and models. Regarding included competences, the most commonly found across the reviewed frameworks are Critical Thinking, Connections, Participation in Community and Learning to Live Together that have been identified as those that educators need to face current sustainability challenges from a transformative perspective. However, other critical competences in this regard, such as Emotions Management, Futures or Uncertainty are less addressed. In this line, results also suggest that the reviewed studies widely emphasize the competences that belong to the Learning to Do group both conceptually but also into practice when developing pedagogical strategies, whereas other more holistic competences belonging to the Learning to Be group are still receiving less attention. Further studies should explore innovative ways to approach these emotional and more holistic competences in the practical arena. Furthermore, research should continue analyzing the transformational potential of different frameworks and models of competences, approaches and pedagogies, considering the specific role of the educators in Sustainability Education.

Supplementary Materials: The supplementary materials are available online at http://www.mdpi.com/2071-1050/ 12/23/9858/s1.

Author Contributions: Conceptualization, A.C. and I.R.-M.; methodology, A.C. and I.R.-M.; validation, A.C. and I.R.-M.; formal analysis, A.C. and I.R.-M.; writing-original draft preparation, A.C.; writing-review and editing, A.C., I.R.-M., M.R. and A.E.; visualization, A.C. and I.R.-M.; supervision, I.R.-M., M.R. and A.E.; funding acquisition, A.C. and I.R.-M. All authors have read and agree to the published version of the manuscript.

Funding: A.C. has been funded by the Universitat Oberta de Catalunya through a Doctoral Thesis Grant. I.R.-M. gratefully acknowledges the financial support of the Spanish State Research Agency through a 'Ramón y Cajal' research fellowship (RYC-2015-17676). I.R.-M. and M.R. also acknowledge funding by the European's Union Erasmus+ program under grant agreement No. 2018-1-UK01-KA203-048121 "RSP II: A Rounder Sense of Purpose II (RSPII)".

Acknowledgments: We thank two anonymous reviewers for their feedback on an earlier version of this paper. Conflicts of Interest: The authors declare no conflict of interest. 


\section{References}

1. Pereira, F. Teacher Education, Teachers' Work, and Justice in Education: Third Space and Mediation Epistemology. Aust. J. Teach. Educ. 2019, 44. [CrossRef]

2. UNESCO. Rethinking Education: Towards a Global Common Good? UNESCO: Paris, France, 2015; Available online: https://unevoc.unesco.org/e-forum/RethinkingEducation.pdf (accessed on 22 October 2020).

3. Díaz-Barriga, A. El enfoque de competencias en la educación. Perf. Educ. 2006, 28, 7-36. Available online: https://www.redalyc.org/pdf/132/13211102.pdf (accessed on 22 October 2020).

4. Barbeito, C.; Egea, A.; Flores, M.; Massip, C. Competències per Transformer el Món. Cap a una Educación Crítica $i$ Per a La Justicia Global a l'escola, 1era ed.; Editorial Graó: Barcelona, España, 2018.

5. Díaz-Barriga, F. Evaluación de Competencias en Educación Superior: Experiencias en el Contexto Mexicano. Rev. Iberoam. Evaluación Educ. 2019, 12, 49-66. [CrossRef]

6. Rieckmann, M. Future-oriented higher education: Which key competencies should be fostered through university teaching and learning? Futures 2012, 44, 127-135. [CrossRef]

7. Australian Research Institute for Environment and Sustainability (ARIES). Education for Sustainability: The Role of Education in Engaging and Equipping People for Change; Department of the Environment, Water, Heritage and the Arts, Australian Research Institute in Education for Sustainability, Macquarie University: Sydney, Australia, 2009; Available online: http://aries.mq.edu.au/publications/aries/efs_brochure/pdf/efs_brochure. pdf (accessed on 22 October 2020).

8. Sauvé, L.; Orellana, I. La formación continua de profesores en educación ambiental: La propuesta de EDAMAZ. In A Contribuição da Educação Ambiental à Esperança de Pandora, 2nd ed.; Sato, M., Santos, J.E.D., Eds.; RiMa: São Carlos, Brazil, 2002; pp. 273-288.

9. Wals, A.E.J.; Jickling, B. Sustainability in higher education: From doublethink and newspeak to critical thinking and meaningful learning. Int. J. Sustain. High. Educ. 2002, 3, 221-232. [CrossRef]

10. Grange, L.L. Environmental Education after Sustainability. In Post-Sustainability and Environmental Education, 1st ed.; Jickling, B., Sterling, S., Eds.; Palgrave Macmillan: Cham, Switzerland, 2017; pp. 93-107. [CrossRef]

11. Bürgener, L.; Barth, M. Sustainability competencies in teacher education: Making teacher education count in everyday school practice. J. Clean. Prod. 2018, 174, 821-826. [CrossRef]

12. European Comission. Supporting Teacher Competences Development for Better Learning Outcomes; European Comission: Brussels, Belgium, 2013; Available online: https:/ec.europa.eu/assets/eac/education/expertsgroups/2011-2013/teacher/teachercomp_en.pdf (accessed on 22 October 2020).

13. Rieckman, M. Key themes in education for sustainable development. In Issues and Trends in Education for Sustainable Development; Leicht, A., Heiss, J., Byun, W.J., Eds.; UNESCO: Paris, France, 2018; pp. 39-59. Available online: https://europa.eu/capacity4dev/file/69206/download?token=r_65VVK_(accessed on 22 October 2020).

14. Rieckmann, M.; Mindt, L.; Gardiner, S. Education for Sustainable Development Goals: Learning Objectives; UNESCO: Paris, France, 2017; Available online: https://unesdoc.unesco.org/ark:/48223/pf0000247444 (accessed on 22 October 2020).

15. Blenkinsop, S. Six Touchstones for Wild Pedagogies in Practice. In Wild Pedagogies Touchstones for Re-Negotiating Education and the Environment in the Anthropocene, 1st ed.; Jickling, B., Blenkinsop, S., Timmerman, N., De Dannan, M., Eds.; Palgrave Studies in Educational Futures: Cham, Switzerland, 2018; pp. 77-108. [CrossRef]

16. Pihkala, P. Environmental Education after Sustainability: Hope in the Midst of Tragedy. Glob. Discourse 2017, 7, 109-127. [CrossRef]

17. Mulà, I.; Tilbury, D.; Ryan, A.; Mader, M.; Dlouhá, J.; Mader, C.; Benayas, J.; Dlouhý, J.; Alba, D. Catalysing Change in Higher Education for Sustainable Development: A review of professional development initiative for university educators. Int. J. Sustain. High. Educ. 2017, 18, 798-820. [CrossRef]

18. UNECE. Learning for the Future: Competences in Education for Sustainable Development; United Nations Economic Commission for Europe: Geneva, Switzerland, 2012; Available online: https://www.unece.org/fileadmin/ DAM/env/esd/ESD_Publications/Competences_Publication.pdf (accessed on 22 October 2020).

19. Sleurs, W. Competencies for ESD (Education for Sustainable Development) Teachers: A Framework to Integrate ESD in the Curriculum of Teacher Training Institutes; Curriculum, Sustainable Development, Competences, Teacher Training (CSCT) Comenious 2.1 Project ; UN: Brussels, Belgium, 2008; Available online: https://www.unece. org/fileadmin/DAM/env/esd/inf.meeting.docs/EGonInd/8mtg/CSCT\%20Handbook_Extract.pdf (accessed on 22 October 2020). 
20. Bertschy, F.; Künzli, C.; Lehmann, M. Teachers' Competencies for the Implementation of Educational Offers in the Field of Education for Sustainable Development. Sustainability 2013, 5, 5067-5080. [CrossRef]

21. Haddaway, N.R.; Woodcock, P.; Macura, B.; Collins, A. Making literature reviews more reliable through application of lessons from systematic reviews. Conserv. Biol. 2015, 1-10. [CrossRef]

22. Vare, P.; Arro, G.; de Hammer, A.; Gobbo, G.G.; de Vries, G.; Farioli, F.; Kadji-Beltran, C.; Kangur, M.; Mayer, M.; Millican, R.; et al. Devising a competence-based training program for educators of sustainable development: Lessons learned. Sustainability 2019, 11, 1890. [CrossRef]

23. Garcia, M.R.; Junyent, M.; Fonolleda, M. How to assess profesional competencies in Education for Sustainability? An approach from a perspective of complexity. Int. J. Sustain. High. Educ. 2017, 18, 772-797. [CrossRef]

24. Meyer, J.; Mader, M.; Zimmermann, F.; Çabiri, K. Training sessions fostering transdisciplinary collaboration for sustainable development: Albania and Kosovo case studies. Int. J. Sustain. High. Educ. 2017, 18, 738-757. [CrossRef]

25. Winter, J.; Cotton, D.; Warwick, P. The University as a Site of Socialization for Sustainability Education. In Teaching Education for Sustainable Development at University Level; Leal Filho, W., Pace, P., Eds.; Springer: Cham, Switzerland, 2016; pp. 1-11. [CrossRef]

26. Albareda-Tiana, S.; García-González, E.; Jiménez-Fontana, R.; Solís-Espallargas, C. Implementing pedagogical approaches for ESD in initial teacher training at Spanish universities. Sustainability 2019, 11, 4927. [CrossRef]

27. Carracedo, F.S.; Segalàs, J.; Vidal, E.; Martin, C.; Climent, J.; López, D.; Cabré, J. Improving engineering educators' sustainability competencies by using competency maps. The EDINSOST project. Int. J. Eng. Educ. 2018, 34, 1527-1537. Available online: https://www.researchgate.net/publication/329151613_Improving_Engineering Educators\%27_Sustainability_Competencies_by_using_Competency_Maps_The_EDINSOST_Project (accessed on 22 October 2020).

28. De Kraker, J.; Dlouhá, J.; Machackova Henderson, L.; Kapitulcinová, D. The European virtual seminar on sustainable development as an opportunity for staff ESD competence development within university curricula. Int. J. Sustain. High. Educ. 2016, 18, 758-771. [CrossRef]

29. Cebrián, G.; Junyent, M. Competencies in education for sustainable development: Exploring the student teachers' views. Sustainability 2015, 7, 2768-2786. [CrossRef]

30. Rauch, F.; Steiner, R. Competences for Education for Sustainable Development in Teacher Education. Cent. Educ. Policy Stud. J. 2013, 3, 9-24. Available online: https://www.pedocs.de/volltexte/2013/7663/pdf/ cepsj_20013_1_Rauch_Steiner_Competences_for_education_for_sustainable_development.pdf (accessed on 22 October 2020).

31. Albareda-Tiana, S.; Vidal-Raméntol, S.; Pujol-Valls, M.; Fernández-Morilla, M. Holistic approaches to develop sustainability and research competencies in pre-service teacher training. Sustainability 2018, 10, 3698. [CrossRef]

32. Álvarez-García, O.; García-Escudero, L.Á.; Salvà-Mut, F.; Calvo-Sastre, A. Variables influencing pre-service teacher training in education for sustainable development: A case study of two Spanish universities. Sustainability 2019, 11, 4412. [CrossRef]

33. Pipere, A.; Mičule, I. Mathematical identity for a sustainable future: An interpretative phenomenological analysis. J. Teach. Educ. Sustain. 2014, 16, 5-31. [CrossRef]

34. Varela-Losada, M.; Arias-Correa, A.; Vega-Marcote, P. Training teachers committed to climate change mitigation. In Climate Literacy and Innovations in Climate Change Education. Distance Learning for Sustainable Development; Azeitero, U., Leal Filho, W., Aires, L., Eds.; Springer: Cham, Switzerland, 2018; pp. 307-321. [CrossRef]

35. Hsieh, H.F.; Shannon, S.E. Three approaches to qualitative content analysis. Qual. Health Res. 2005, 15, 1277-1288. [CrossRef] [PubMed]

36. Wiek, A.; Withycombe, L.; Redman, C.L. Key competencies in sustainability: A reference framework for academic program development. Sustain. Sci. 2011, 6, 203-218. [CrossRef]

37. NAAEE. Guidelines for Excellence K-12 Learning; North American Association for Environmental Education: Washington, DC, USA, 2010; Available online: https://cdn.naaee.org/sites/default/files/learnerguidelines_ new.pdf (accessed on 22 October 2020).

38. Yavetz, B.; Goldman, D.; Pe'er, S. Environmental literacy of pre-service teachers in Israel: A comparison between students at the onset and end of their studies. Environ. Educ. Res. 2009, 15, 393-415. [CrossRef] 
39. Simmons, B. Guidelines for the Preparation and Professional Development of Environmental Educators; North American Association for Environmental Education: Washington, DC, USA, 2000; Available online: https: //naaee.org/sites/default/files/g1_preservice_complete.pdf (accessed on 22 October 2020).

40. Barth, M.; Rieckmann, M. State of the Art in Research on Higher Education for Sustainable Development. In Routledge Handbook of Higher Education for sustainable Development; Barth, M., Michelsen, G., Thomas, I., Rieckmann, M., Eds.; Routledge: London, UK, 2016; pp. 100-113. [CrossRef]

41. Sterling, S. Learning for resilience, or the resilient learner? Towards a necessary reconciliation in a paradigm of sustainable education. Environ. Educ. Res. 2010, 16, 511-528. [CrossRef]

42. Pol, E.; Castrechini, A. ¿Disrupción en la educación para la sostenibilidad? Revista Latinoamericana de Psicología 2013, 45, 335-349. [CrossRef]

43. Mezirow, J. Transformative Learning: Theory to Practice. New Dir. Adult Contin. Educ. 1997, 74, 5-12. [CrossRef]

44. Sterling, S. Transformative learning and sustainability: Sketching the conceptual ground. Learn. Teach. High. Educ. 2011, 5, 17-33.

45. Williams, L. Transformative Sustainability Education and Empowerment Practice on Indigenous Lands: Part One. J. Transform. Educ. 2018, 16, 344-364. [CrossRef]

46. Weston, A. Before Environmental Ethics. Env. Ethics 1992, 14, 321-338. [CrossRef]

47. Jickling, B. Education Revisited: Creating Educational Experiences That Are Held, Felt, and Disruptive. In Post-Sustainability and Environmental Education, 1st ed.; Jickling, B., Sterling, S., Eds.; Palgrave Macmillan: Cham, Switzerland, 2017; pp. 15-30. [CrossRef]

Publisher's Note: MDPI stays neutral with regard to jurisdictional claims in published maps and institutional affiliations.

(C) 2020 by the authors. Licensee MDPI, Basel, Switzerland. This article is an open access article distributed under the terms and conditions of the Creative Commons Attribution (CC BY) license (http://creativecommons.org/licenses/by/4.0/). 